p-ISSN: $2338-4794$

e-ISSN: 2579-7476

Vol.8. No. 3 September-Desember 2020

\title{
PENGARUH LAYOUT DAN STANDARD OPERATING PROCEDURE TERHADAP PRODUKTIVITAS KARYAWAN EMP MALACCA STRAIT PSC
}

\author{
Eka Noviati ${ }^{1)}$ \\ 1) Mahasiswa Program Studi Manajemen FE UNKRIS \\ Imam Wibowo ${ }^{2)}$ \\ 2) Dosen Program Studi Manajemen FE UNKRIS \\ Alamat: Kampus UNKRIS, Jatiwaringin Jakarta Timur \\ Email : wibowoimam253@gmail.com
}

\begin{abstract}
This research aims to know layout and standard operating procedure impact to company's productivity. Population from this research are employee production division of EMP Malacca Strait PSC as more as 200 persons and sample used are 115 respondents. Research method used is quantitative method, analysis technique multiple regression and simple regression. Research result showing that layout and standard operating procedure partially and together had a positive and significant to productivity. Particularly in production, it is still necessary to make improvements in terms of the tidiness of the layout area, which is further enhanced by providing training and continuous understanding of standard operating procedures and scheduled $5 R$ activities every day.
\end{abstract}

Keyword: Layout, standard operating procedure, productivity.

\section{PENDAHULUAN}

Migas merupakan industri yang mempunyai resiko tinggi (high risk), dari kegiatan eksplorasi dan produksi, pengolahan sampai kepada pemasaran. Beberapa tahun terakhir naik turunnya produktivitas menjadi topik utama sebuah perusahaan dalam menganalisa pencapaianya, sehingga produktivitas akan selalu menjadi patokan sebagai tolak ukur seberapa besar hasil yang didapatkan dan seefektifitas dan seefisien apa perusahaan dalam pencapainnya. Product: result, outcome kemudian berkembang menjadi productive yang berarti menghasilkan, dan productivity having the ability or creative adalah asal mula kata produktivitas. Produktivitas (productivity) merupakan rasio hasil (barang dan jasa) dibagi dengan masukan (sumber daya seperti buruh dan modal) adalah pengertian menurut Heizer dan Render (2015). Dari pengertian diatas dapat ditarik pengertian bahwa produktivitas adalah kemampuan menghasilkan sesuatu dari rasio hasil (barang dan jasa) dan masukan (modal dan buruh) dimana untuk hasil semaksimal mungkin dapat dipengaruhi oleh faktor supply chain management, layout yang tepat, standard operating procedure, modal, sumber daya manusia atau ini dapat diartikan juga sebagai peningkatan efisiensi.

Dalam peningkatan produktivitas untuk mencapai hasil maksimal faktor 
penerapan layout yang tepat haruslah menjadi perhatian utama. Layout menurut Heizer dan Render (2015) adalah salah satu dari keputusan utama yang menentukan efesiensi jangka panjang suatu operasi. Layout memiliki implikasi strategis karena ia menciptakan prioritas kompetitif sehubungan dengan kapasitas, proses, fleksibilitas, dan biaya, dan begitu pula dengan kualitas kehidupan kerja, kontak pelanggan dan citra. Faktor yang begitu penting dalam meningkatkan produktivitas adalah standard operating procedure yang terintegrasi sehingga hasil yang diharapkan akan semaksimal mungkin dan untuk menghindari kesalahan sekecil mungkin. Budihardjo (2014) mengartikan standard operating procedure sebagai suatu perangkat lunak pengatur, yang mengatur tahapan suatu proses kerja atau prosedur kerja tertentu.

Tujuan dalam penelitian ini yaitu: Untuk mengetahui pengaruh Layout dan standard operating procedure terhadap produktivitas di EMP Malacca Strait PSC.

\section{LANDASAN TEORI}

\section{Produktivitas}

Menurut Heizer dan Render (2015) produktivitas berasal dari dua kata yaitu product: result, outcome kemudian berkembang menjadi productive yang berarti menghasilkan, dan productivity having the ability or creative. Produktivitas (productivity) merupakan rasio hasil (barang dan jasa) dibagi dengan masukan (sumber daya seperti buruh dan modal). Sedangkan menurut Handoko (2011) ikatan antara masukanmasukan dan keluaran-keluaran suatu sistem produktif. Dalam teori, sering mudah untuk mengukur hubungan ini sebagai rasio keluaran dibagi masukan.
Bila lebih banyak keluaran diproduksi dengan jumlah masukan sama, produktivitas naik. Begitu pula, bila lebih sedikit masukan digunakan untuk sejumlah keluaran sama, produktivitas juga naik. Daryanto dan Raharjo (2012) mengartikan produktivitas sebagai sebuah konsep yang menggambarkan hubungan antara hasil (jumlah barang dan atau jasa yang diproduksi) dengan sumber (jumlah tenaga kerja, modal, tanah, energi, dan sebagainya) untuk menghasilkan hasil tersebut. Adapun menurut Stevenson dan Chuong (2014) produktivitas (productivity) adalah indeks yang mengatur output (barang dan jasa) dibandingkan dengan input (tenaga kerja, bahan baku, energi, dan sumber daya lainnya) yang digunakan untuk memproduksi output.

Produktivitas juga mengandung pengertian filosofi, definisi kerja, dan operasional. Secara filosofi menurut Simanjuntak (2011) "produktivitas merupakan pandangan hidup dan sikap mental yang selalu berusaha untuk meningkatkan mutu kehidupan". Keadaan hari ini harus lebih baik dari kemarin dan mutu kehidupan besok harus lebih baik dari hari ini.

Indikator dari produktivitas menurut Stevenson dan Chuong (2014) diantaranya: 1). Modal. 2). Mutu. Dan 3). Manajemen.

\section{Tata Letak (Layout)}

Menurut Heizer dan Render (2015) adalah salah satu dari keputusan utama yang menentukan efesiensi jangka panjang suatu operasi. Layout memiliki implikasi strategis karena ia menciptakan prioritas kompetitif sehubungan dengan kapasitas, proses, fleksibilitas, dan biaya, dan begitu pula dengan kualitas kehidupan kerja, kontak pelanggan dan citra. Adapun menurut Arif (2017) layout adalah susunan 
departemen, tempat kerja, dan peralatan, dengan perhatian utama pada gerakan kerja (pelanggan atau material) melalui sistem, tata letak tetap (fix-position layout), tata letak proses (process layout), tata letak produk (product layout), atau tata letak kombinasi (combination layout). Menurut Herjanto (2008) merupakan salah satu tahap dalam perencanaan fasilitas yang bertujuan untuk mengembangkan suatu sistem produksi yang efisien dan efektif sehingga dapat tercapainya suatu proses produksi dengan biaya yang paling ekonomis. Sedangkan menurut Yamit (2005) layout adalah rencana pengaturan semua fasilitas produksi guna memperlancar proses produksi yang efektif dan efisien. Haming dan Nurnajamuddin (2011) menyatakan bahwa, tata letak memiliki berbagai pengaruh yang strategis yang berlangsung dalam jangka waktu yang lama. Tata letak menentukan daya saing perusahaan dalam hal kecukupan kapasitas, kelancaran proses, fleksibilitas operasi dan biaya penanganan bahan serta kenyamanan kerja.

Penelitian yang dilakukan oleh Mubarok dan Lukmandono (2017) menghasilkan bahwa layout memberikan pengaruh positif dengan dapat mengefisiensi MHC sebesar $32.55 \%$ dengan peningkatan produktivitas sebesar $5.025 \%$. Penelitian yang dilakukan Wiyaratn dan Watanapa (2010) menghasilkan bahwa mengatur kembali layout mengurangi alur material, dihasilkan dalam meningkatkan produktivitas.

Indikator layout menurut menurut Yamit (2005) antar lain: 1) Urutan proses, apakah atas dasar arus (flow) atau atas dasar proses. 2). Mesin-mesin (Pemeliharaan dan penggantian). 3). Area tenaga kerja (employee area).

\section{Prosedur Standar Operasi (Standard Operating Procedure)}

Menurut Insani (2010) standard operating procedure dokumen yang berisi serangkaian instruksi tertulis yang dibakukan mengenai berbagai proses penyelenggaraan proses administrasi perkantoran yang berisi cara melakukan pekerjaan, waktu pelaksanaan, tempat penyelenggaraan dan aktor yang berperan dalam kegiatan. Sedangkan menurut Wibowo (2010) mengungkapkan standard operating procedure merupakan standar kegiatan yang harus dilakukan secara berurutan untuk menyelesaikan suatu pekerjaan dan apabila ditaati akan membawa akibat seperti: lancarnya koordinasi, tidak terjadi tumpang tindih atau duplikasi, terbinanya hubungan kerja yang serasi, kejelasan wewenang dan tanggung jawab setiap pegawai. Standard operating procedure mempunyai kriteria efektif dan efisien, sistematis, konsisten, sebagai standar kerja, mudah dipahami, lengkap, tertulis dan terbuka untuk berubah atau fleksibel. Menurut Fatimah (2015) standard operating procedure adalah pedoman atau acuan untuk melaksanakan tugas pekerjaan sesuai dengan fungsi dan alat penilaian kinerja instansi pemerintah. Sedangkan menurut Santosa (2014) menjelaskan standard operating procedure ialah "Sekumpulan tulisan yang memuat langkah-langkah khusus yang spesifik, yang menjelaskan tiap detail dari aktivitas untuk menyempurnakan tugas-tugas sesuai dengan regulasi, perusahaan, kesehatan, pendidikan, penerbangan, perindustrian, militer atau bahkan menjalankan usaha kecil". Menurut Ekotama (2013) standard operating procedure atau prosedur standar operasi adalah suatu sistem yang digunakan guna merapihkan, memudahkan serta menertibkan pekerjaan yang kita 
lakukan. Hartatik (2014) menerangkan bahwa yang dimaksud dengan standard operating procedure adalah "sebuah acuan kerja yang baik, baku dan dapat mempermudah mengontrol dan mengendalikan kegiatan operasional dalam suatu perusahaan." Adapun menurut Purnamasari (2015) standard operating procedure diartikan prosedur kerja yang dibuat secara detail dan terperinci bagi semua karyawan untuk melaksanakan pekerjaan dengan sebaik mungkin sesuai dengan misi, visi dan tujuan perusahaan. Dan menurut Sailendra (2015) merupakan panduan yang digunakan untuk memastikan kegiatan operasional organisasi atau perusahaan berjalan dengan lancar.

Penelitian yang dilakukan Pambudi dan Saputro (2014) menghasilkan bahwa S.O.P, standarisasi layout yang baru, dan disediakan meja kerja pada area receiving memberikan pengaruh yang positif dan signifikan terhadap peningkatan produktivitas perusahaan sehingga metode atau sistem kerja yang ada dapat berubah lebih ergonomi, tidak ada lagi gerakan membungkuk dari operator, alur proses lebih jelas, dan tidak ada lagi barangbarang yang tidak diproses berada pada area tersebut, sehingga area receiving dapat digunakan secara maksimal. Penelitian yang dilakukan oleh Chandurkar, Kakde dan Bhadane (2015) menghasilkan penelitiannya yaitu konsep yang diterapkan disini adalah faktor penting untuk meningkatkan produktivitas dan efisiensi industri. Dalam proyek ini dengan SOP baru dapat mengurangi waktu operasi sebesar 22.91 detik serta meningkatkan efisiensi operasi.

Indikator dari standar prosedur operasi menurut Insani (2010) antara lain:
1). Sistem kerja. 2). Tugas SDM. dan 3). Prosedur kerja.

\section{METODE PENELITIAN}

\section{Rancangan Penelitian}

Penelitian ini dirancang untuk menjelaskan pengaruh layout dan standard operating procedure terhadap produktivitas EMP Malacca Strait PSC baik secara parsial maupun secara simultan. Data yang digunakan dalam penelitian ini merupakan data primer dan sekunder melalui pengisian kuesioner kepada para karyawan EMP Malacca Strait PSC divisi produksi.

\section{Metode Pengumpulan Data}

Penelitian ini di lakukan di EMP Malacca Strait PSC yang berlokasi di Rasuna Epicentrum, Bakrie Tower, Lantai 27 sampai 32, Jalan HR. Rasuna Said, Jakarta Selatan, Jakarta -Indonesia. Data yang dikumpulkan adalah data primer yang didapat melalui pengisian kuesioner oleh karyawan EMP Malacca Strait PSC dengan menggunakan model skala Semantic Differential. Dimana skala ini terdapat dua kutub yaitu positif dan negatif. Menurut Sugiyono (2015) skala pengukuran yang berbentuk semantic differensial dikembangkan dan dikenalkan oleh Charles Osgood. Skala ini juga digunakan untuk mengukur sikap hanya bentuknya tidak pilihan ganda maupun checklist, tetapi tersusun dalam satu garis kontinum yang mana jawaban "sangat positif" terletak di bagian kiri garis, dan jawaban yang "sangat negatif" terletak di bagian kanan garis, atau sebaliknya. Variabel yang akan diukur, diuraiakan menjadi indikator variabel.

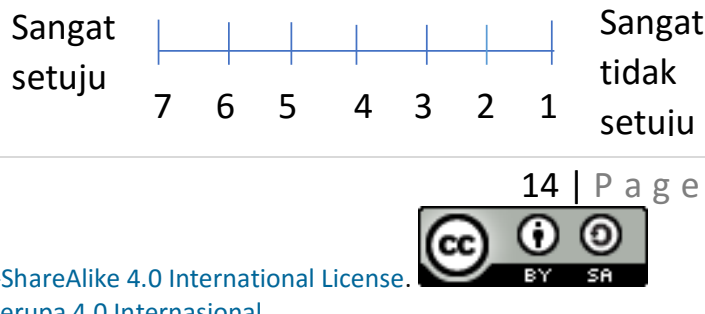

This work is licensed under a Creative Commons Attribution-NonCommercial-ShareAlike 4.0 International License.

Ciptaan disebarluaskan di bawah Lisensi Creative Commons Atribusi-BerbagiSerupa 4.0 Internasional. 


\section{Gambar 1: Skala Semantic Differential}

Menurut Sugiyono (2015) populasi adalah "wilayah generalisasi yang terdiri atas obyek atau subjek yang mempunyai kualitas dan karakteristik tertentu yang ditetapkan oleh peneliti untuk dipelajari dan kemudian ditarik kesimpulannya".

Populasi untuk penelitian ini adalah karyawan divisi produksi dari EMP Malacca Strait PSC yang berjumlah 200 orang. Menurut Sugiyono (2015) sampel adalah "bagian dari jumlah dan karakteristik yang dimiliki oleh populasi tersebut Bila populasi besar, dan peneliti tidak mungkin mempelajari semua yang ada pada populasi, misalnya karena keterbatasan dana, tenaga, dan waktu, maka peneliti dapat menggunakan sampel yang diambil dari populasi itu. Apa yang dipelajari sampel itu, kesimpulannya akan dapat diberlakukan untuk populasi. Untuk itu sampel yang diambil dari populasi harus betul-betul representatif (mewakili).

Berdasarkan hasil rekapitulasi dengan menggunakan rumus Isaac dan Michael dengan total dari populasi 200 orang, tingkat kesalahan $10 \%$, maka diketahui ukuran atau total sampel dalam penelitian ini yaitu sebesar 115 responden.

$$
S=\frac{\lambda^{2} \cdot N \cdot P \cdot(1-P)}{d^{2}(N-1)+\lambda^{2} \cdot P \cdot(1-P)}
$$

Sumber: Sugiyono (2015)

Dengan diketahui total dari data karyawan EMP Malacca Strait PSC, maka dalam penelitian ini memakai metode teknik probability sampling. Menurut Sugiyono (2015) "teknik pengambilan sampling merupakan teknik dalam sampel”. Peluang yang menyerupai bagi setiap unsur atau elemen untuk dipilih menjadi anggota sampel dengan memakai teknik pengambilan sampel merupakan arti dari teknik probability sampling". Populasi yang dilakukan secara random dalam pengambilan anggota sampel bisa dilakukan tanpa memperhatikan strata yang terdapat dalam populasi disebut teknik dengan menggunakan simple random sampling atau simple.

Guna memberikan hasil yang relevan dan obyektif dalam metode pengumpulan data penelitian pengaruh layout dan standard operating procedure terhadap produktivitas EMP Malacca Strait PSC, maka dalam penelitian ini menggunakan studi literatur dan studi lapangan Dalam penelitian pengumpulan data studi lapangan menggunakan teknik pengumpulan data berupa wawancara tidak terstruktur dilakukan dengan cara kuesioner (angket), bertatap muka (face to face), dan pengumpulan data observasi partisipan (Participant Observation).

Untuk memberikan hasil yang relevan dan obyektif dalam teknik analisis data tentang penelitian pengaruh layout dan standard operating procedure terhadap produktivitas EMP Malacca Strait PSC, maka teknik analisisi data kuantitatif dipakai dalam penelitian ini. Data diperoleh dari berbagai sumber, dengan memakai teknik pengumpulan data. Instrumen yang dipakai dalam memperoleh data (mengukur) valid. Instrumen yang valid berarti dapat dipakai untuk mengukur apa yang sebenarnya diukur. Menurut Sugiyono (2015) "validitas adalah tingkatan akurasi antara data yang terjadi pada objek penelitian dan data yang dapat di informasikan oleh peneliti". Menurut Sugiyono (2015) "perangkat atau instrumen apabila dipakai berulang-ulang untuk menghitung obyek yang sama, akan 
mendapatkan informasi yang serupa merupakan pengertian uji reliabilitas".

\section{Model Analisis Data}

Untuk menganalisis pengaruh layout dan standard operating procedure terhadap produktivitas EMP Malacca Strait PSC digunakan metode analisis regresi linier berganda, dimana analisis linier berganda guna melihat tidak ada atau adanya efek keseluruhan variabel $\mathrm{X}$ (variabel bebas) dimana dalam hal ini variabel layout dan standard operating procedure atas varibel Y (variabel terikat) dimana dalam hal ini variabel produktivitas. Pembuktian dari pengaruh layout dan standard operating procedure terhadap produktivitas di EMP Malacca Strait PSC, kemudian dipakai analisis regresi linier berganda.

$$
\mathrm{Y}=\mathrm{b}_{\mathrm{o}}++\mathrm{b}_{1} \mathrm{X}_{1}+\mathrm{b}_{2} \mathrm{X}_{2}+\varepsilon
$$$$
\text { Sumber: Sugiyono (2011) }
$$

\section{Analisis regresi linear sederhana}

Keterangan:

\begin{tabular}{|c|c|}
\hline Y & $=$ Produktivitas \\
\hline$b_{o}$ & $=$ Bilangan konstanta \\
\hline$b_{1}, b_{2}$, & = Koefisien regresi. \\
\hline $\mathrm{X}_{1}$ & $=$ Layout \\
\hline $\mathrm{X}_{2}$ & $\begin{aligned}= & \text { Standard Operating } \\
& \text { Procedure. }\end{aligned}$ \\
\hline $\mathcal{E}$ & $=$ Error, variabel gangguan. \\
\hline
\end{tabular}

\section{HASIL PENELITIAN DAN PEMBAHASAN}

\section{Hasil Penelitian}

\section{Uji Validitas dan Uji Reliabilitas}

Variabel penelitian yang terdiri dari produksi, supply chain management, dan kaizen keseluruhan memiliki 39 butir pernyataan. Hasil pengujian terhadap 39 butir pernyataan dinyatakan valid dan reliabel.

Tabel 1. Pengaruh Layout Terhadap Produktivitas

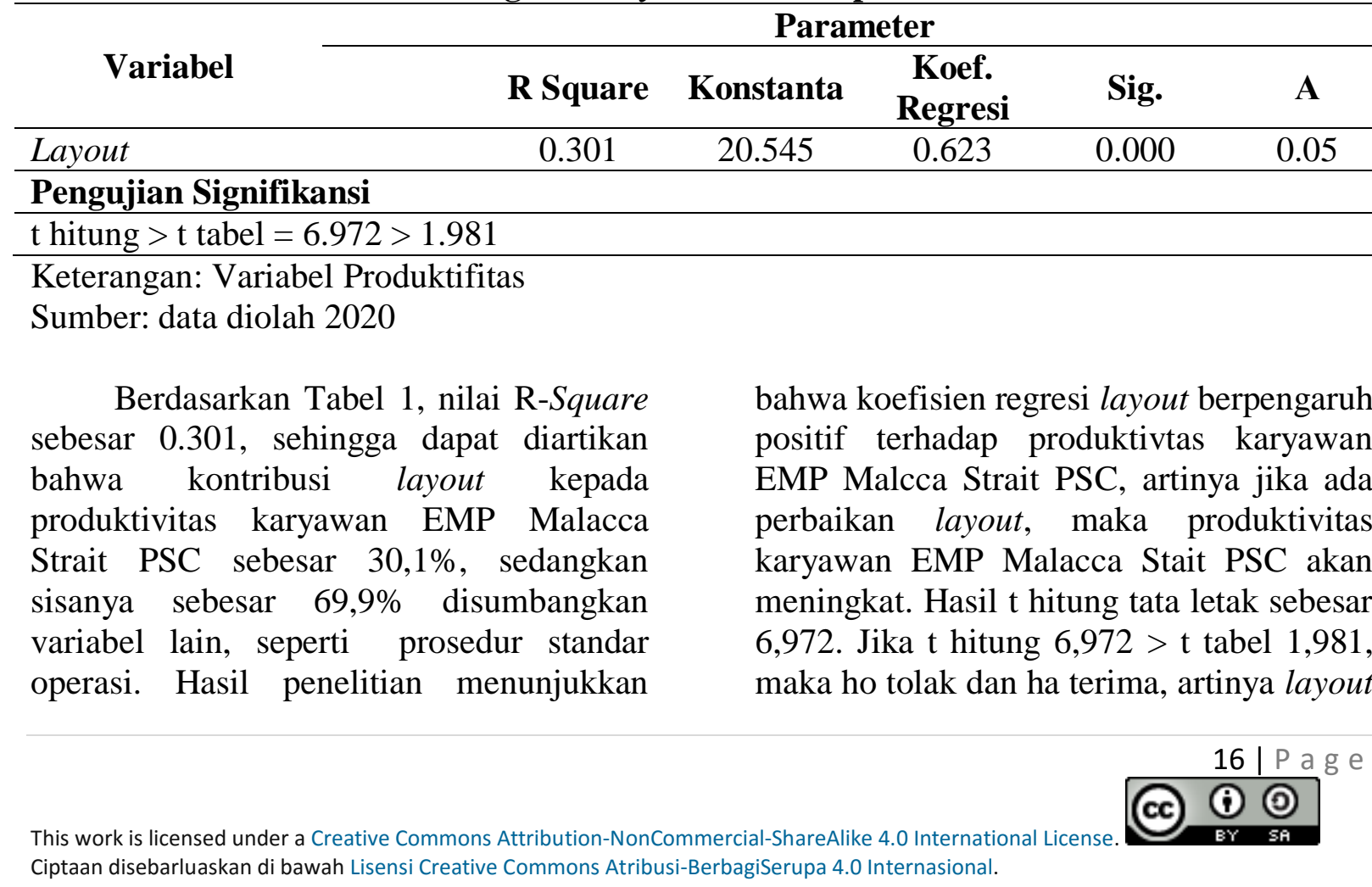




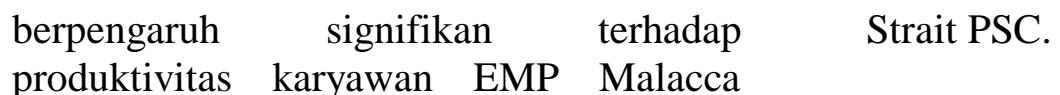

Tabel 2. Pengaruh Standard Operating Procedure Terhadap Produktivitas

\begin{tabular}{lccccc}
\hline \multirow{2}{*}{ Variabel } & R Square & Konstanta & $\begin{array}{c}\text { Koef. } \\
\text { Regresi }\end{array}$ & Sig. & A \\
\cline { 2 - 7 } & 0.270 & 24.461 & 0.524 & 0.000 & 0.05 \\
\hline SOP & & & & & \\
\hline Pengujian Signifikansi & & & & & \\
\hline $\mathrm{t}$ hitung $>\mathrm{t}$ tabel $=6.473>1.981$ & &
\end{tabular}

Keterangan: Variabel Produktifitas

Sumber: data diolah 2020

Berdasarkan Tabel 2, nilai R-Square sebesar 0,270, sehingga dapat diartikan bahwa kontribusi standard operating procedure kepada produktivitas karyawan EMP Malacca Strait PSC sebesar 27,0\%, sedangkan sisanya sebesar $73,0 \%$ disumbangkan variabel lain, seperti tata letak. Hasil penelitian menunjukkan bahwa koefisien regresi standard operating procedure berpengaruh positif terhadap produktivtas karyawan EMP Malcca Strait
PSC, artinya jika ada perbaikan standard operating procedure, maka produktivitas karyawan EMP Malacca Stait PSC akan meningkat. Hasil t hitung prosedur standar operasi sebesar 6,473. Jika t hitung 6,473 > $\mathrm{t}$ tabel 1,981, maka ho tolak dan ha terima, artinya standard operating procedure berpengaruh signifikan terhadap produktivitas karyawan EMP Malacca Strait PSC.

\section{Analisis regresi linear berganda}

Tabel 3. Pengaruh Layout dan Standard Operating Procedure Terhadap Produktivitas

\begin{tabular}{lccccc}
\hline \multirow{2}{*}{ Variabel } & R Square & Konstanta & $\begin{array}{c}\text { Koef. } \\
\text { Regresi }\end{array}$ & Sig. & A \\
\cline { 2 - 6 } & 0.435 & 10.048 & 0.485 & 0.000 & 0.05 \\
\hline $\begin{array}{l}\text { Layout } \\
\text { SOP }\end{array}$ & & & & & \\
\hline Pengen
\end{tabular}

Pengujian Signifikansi

F hitung $>$ F tabel $=43.064>3.08$

Keterangan: Variabel Produktifitas

Sumber: data diolah 2020 
Berdasarkan Tabel 3, nilai Sig. sebesar $0,000<0,05$ dan $\mathrm{F}$ hitung layout dan standard operating procedure sebesar 43,064 dan F tabel sebesar 3,08, Jika niai Sig. $0,000<0,05$ dan F hitung $=43,064>$ $\mathrm{F}$ tabel $=3,08$, maka tolak ho dan ha terima, artinya ada pengaruh secara bersama-sama layout dan standard operating procedure terhadap produktivitas karyawan EMP Malacca Strait PSC. Nilai R-Square sebesar 0,435, seingga dapat diartikan bahwa kontribusi layout dan standard operating procedure kepada produktivitas karyawan EMP Malacca Strait PSC sebesar 43,5 \%, sedangkan sisanya sebesar $56,5 \%$ disumbangkan variabel lain.

Hasil penelitian menunjukan bahwa koefisien regresi layout dan standard operating procedure berpengaruh positif dan signifikan terhadap produktivitas karyawan EMP Malacca Strait PSC. Koefisien regresi layout bertanda positif, artinya jika ada perbaikan layout, maka produktivitas karyawan EMP Malacca Strait PSC akan meningkat dengan asumsi standard operating procedure tidak berubah. Koefisien regresi standard operating procedure bertanda positif, artinya jika ada perbaikan standard operating proedure, maka produktivitas karyawan EMP Malacca Strait PSC akan meningkat dengan asumsi layout tidak berubah.

\section{Pembahasan}

\section{Pengaruh Layout Terhadap Produktivitas}

Perbaikan layout akan meningkatkan produktivitas karyawan EMP Malacca Strait PSC, karena susunan atau penempatan kerja sesuai dengan standard operating procedure sehingga memperlancar proses produksi, pemeliharaan serta penggantian mesin dilakukan secara berkala, serta area tenaga kerja yang bersih sehingga berdampak kepada produktivitas perusahaan. Hal tersebut sesuai hasil penelitian yang dilakukan oleh Syah, et al (2016) menghasilkan penelitiannya yaitu dengan tata letak yang disusun sesuai poses operasi dapat memangkas jarak dan waktu produksi, sehingga alur komunikasi dapat berjalan dengan baik dan lebih lancar. Rancangan tata letak lebih efisien, hal ini dikarenakan alur proses produksi yang sebelumnya panjang dapat diperpendek, aktivitas pekerjaan teroganisir baik, fleksibel dan efektif.

\section{Pengaruh Standard Operating Procedure Terhadap Produktivitas}

Perbaikan standard operating procedure akan meningkatkan produktivitas karyawan EMP Malacca Strait PSC. Hal ini terbukti dengan aktivitas pekerjaan yang dilakukan terorganisir dengan baik, fleksibel, efektif, dan terstruktur. Hal tersebut sesuai hasil penelitian yang dilakukan oleh Abdulloh dan Yani (2017) yang menyatakan prosedur standar operasi khususnya Pelaksanaan sistem shift kerja berpengaruh terhadap produktivitas kerja karyawan.

\section{Pengaruh Layout dan Standard Operating Procedure Terhadap Produktivitas}

Perbaikan layout dan standard operating procedure akan meningkatkan produktivitas karayawan EMP Malacca Strait PSC, karena layout yang dirancang dijalankan sesuai dengan prosedur standar kerja, memperlancar proses kerja, evaluasi secara berkala, memudahkan pemeliharaan mesin dan peralatan, sehingga dapat 
meminimalisir biaya penanganan material, serta didukung dengan standard operating procedure yang terorganisisr, fleksibel, efektif, dikerjakan secara tim, mentaati peraturan, tertulis, terevaluasi dan terstruktur. Hal tersebut sesuai dengan hasil penelitian yang dilakukan oleh Pambudi dan Saputro (2014) dengan hasil penelitiannya yaitu dengan dibuatkan SOP, standarisasi tata letak yang baru, dan disediakan meja kerja pada area receiving maka metode atau sistem kerja yang ada dapat berubah lebih ergonomi, lebih efisien dan berdampak pada produktivitas karyawan.

\section{KESIMPULAN DAN SARAN}

\section{Kesimpulan}

Berdasarkan hasil penelitian yang telah dilakukan dan telah dibahas dalam pembahasan, maka dapat diambil kesimpulan yang dapat diuraikan sebagai berikut: 1). Hasil penelitian memperlihatkan bahwa layout memiliki pengaruh yang signifikan dan positif terhadap produktivitas karyawan. 2). Hasil penelitian membuktikan bahwa standard operating procedure memiliki pengaruh yang signifikan dan positif terhadap produktivitas karyawan. 3). Hasil penelitian menunjukkan bahwa layout dan standard operating procedure memiliki pengaruh prositif dan signifikan terhadap produktivitas karyawan.

\section{Saran}

Dalam peningkatan produktivitas demi tercapainya hasil produksi yang optimal dengan kualitas terbaik dari layout dan standard operating procedure yang tepat EMP Malacca Strait PSC dalam kerapihan area layout lebih ditingkatkan dengan diberikan pelatihan dan pemahaman secara terus menerus terhadap standard operating procedure dan kegiatan 5R yang terjadwal setiap hari, setiap aktivitas selalu terevaluasi, dibuatkan rak atau pallet untuk material yang disimpan di luar ruangan, dan lebih ketat dalam pengontrolan terhadap mutu barang.

\section{DAFTAR PUSTAKA}

Abdulloh, Yayan dan Ari Soeti Yani. 2017. Pengaruh Penerapan Sistem Manajemen Mutu Dan Pelaksanaan Sistem Shift Kerja Terhadap Produktivitas Kerja Karyawan Dimoderasi Standar Operasional Prosedur (Studi Pada Pt. Pan Maritime Wira Pawitra Jakarta). Jurnal Internasional dan Nasional Vol. 5 No. 22017 ISSN: 2502-3632 (online) ISSN: 2356-0304 (Paper).

Arif, Muhammad. 2017. Perancangan Tata Letak Pabrik. Penerbit: CV. Budi Utama. Yogyakarta.

Bhuono Agung, Nugroho. 2005. Strategi Jitu Memilih Metode Statistik Penelitian Dengan SPSS. Penerbit: Andi. Yogyakarta.

Budihardjo, M. 2014. Panduan Praktis Menyusun SOP (Standard Operating Procedure). Penerbit: Raih Asa Sukses (Penebar Swadaya Group). Jakarta.

Chandurkar, Pranjali. Madhuri Kakde. dan Abhishek Bhadane. 2015. Improve the Productivity with help of Industrial Engineering Techniques. International Journal on Textile Engineering and Processes. ISSN: 2395-3578. Vol 1. Issue 4, October 2015.

Daryanto dan Muljo Rahardjo. 2012. Sari Kuliah Manajemen Produksi. Penerbit: Gava Media. Yogyakarta. 
Ekotama, S. 2013. Cara Mudah Bikin Standard Operating Procedure. Penerbit: Media Presindo. Yogyakarta.

Fatimah, E. N. 2015. Strategi Pintar Menyusun SOP. Peneribit: Pustaka Baru Press. Yogyakarta.

Gujarati. 2012.

Dasar-Dasar

Ekonometrika. Terjemahan:

Mangunsong. Edisi: Lima. Penerbit: Salemba Empat. Jakarta.

Haming, Murdifin dan Mahfud

Nurnajamuddin. 2011. Manajemen

Produksi Modern Operasi

Manufaktur dan Jasa. Penerbit: Bumi

Aksara. Jakarta.

Handoko, T. Hani. 2011. Manajemen

Personalia dan Sumberdaya

Manusia. Penerbit: BPFE.

Yogyakarta.

Hartatik, Indah Puji. 2014. Buku Pintar

Membuat Standar Operasional

Prosedur. Penerbit: Flash Book.

Yogyakarta.

Heizer, Jay dan Barry Reinder. 2015. Manajemen Operasi (Manajemen Keberlangsungan dan Rantai Pasokan). Edisi 11. Edisi Bahasa Indonesia. Penerbit: Salemba Empat. Jakarta.

Herjanto, Eddy. 2008. Manajemen Operasi Edisi Ketiga. Penerbit: Grasindo. Jakarta.

Insani, Istyadi. 2010. Standard Operasional Prosedur (SOP) Sebagai Pedoman Pelaksanaan Administrasi Perkantoran Dalam Rangka Peningkatan Pelayanan dan Kinerja Organisasi Pemerintah. Penyempurnaan Makalah pada Workshop Manajemen Perkantoran di Lingkungan Kementrian Komunikasi dan Informatika. Bandung.
Mubarok, Husni \& Lukmandono. 2017. Perancangan Ulang Tata Letak Fasilitas Dengan Pendekatan Metode Systematic Layout Planning Guna Meningkatkan Produktivitas Di CV. Putra Perkasa. ISBN 978-602-985691-0.

Pambudi, Iwan Tutuka. dan Great Saputro. 2014. Meningkatkan Produktivitas Proses Sorting Part Dengan Merubah Sistem Kerja Pada Area Receiving Di Part Distribution Center PT XYZ. Seminar Nasional Inovasi dan Tren 2014.

Permenpan No.PER/21/M.PAN/11/2008. Pedoman Penyusunan Standar Operational Prosedur (SOP) Administrasi Pemerintahan.

Purnamasari, Evita P. 2015. Panduan Menyusun SOP Standard Operating Procedure. Penerbit: PT. Buku Kita. Jagakarsa-Jakarta.

Rashid, M.F.F. Ab, Nik Mohamed, A.N. Mohd Rose and K.Y. Kor. 2015. Simulation Study of a Vehicle Production Line for Productivity Improvement. Journal of Mechanical Engineering and Services (JMES) ISSN (Print): 2289-4659. e-ISSN: 2231-8380. Volume 8. PP. 12831292. June 2015.

Santosa, J.K. 2014. Lebih Memahami SOP. Penerbit: Kata Pena. Surabaya.

Santoso, Singgih. 2010. Statistik Multivariat. Penerbit: PT Elex Media Komputindo. Jakarta.

Santoso, Singgih. 2012. Statistik Multivariat. Penerbit: PT Elex Media Komputindo. Jakarta.

Sailendra, Annie. 2015. Langkah-langkah Praktis Membuat SOP. Cetakan: Pertama. trans idea publishing. Yogyakarta. 
Samsudin, Lalu Moh. Vera Metahlina dan Annisa Purbasari. 2014. Perancangan Ulang Tata Letak Pabrik Jamur Tiram Menggunakan Metode Activity Relationship Chart Untuk Meningkatkan Produktivitas (Studi kasus CV. Mandiri Tiban III). Profesiensi. 2 (1). 19-27 Juni 2014 ISSN. Cetak: 23011-7244.

Simanjuntak. Payaman J. 2011. Manajemen Evaluasi Kinerja. Edisi 3. Fakultas UI. Jakarta.

Sugiyono. 2015. Metode Penelitian (Kualitatif, Kuantitatif, dan R\&D). Cetakan ke-22. Penerbit: Alfabeta CV. Bandung.

Stevenson, J. William dan Sum Chee Chuong. 2014. Manajemen Operasi Perspektif Asia. Penerbit: Salemba Empat. Jakarta.

Syah, Beny Fatkhur Rozaq Alam. Didik Pudjo Musmedi. Eka Bambang Gusminto. 2016. Evaluasi Pelaksanaan Tata Letak Ruang Terhadap Produktivitas Di Rumah
Batik Rolla Jember. Artikel Ilmiah Mahasiswa 2016. Digital Repository Universitas Jember.

Wankhade, Akshay D. and Dr. Achal S. Shahare. 2017. Productivity Improvement by Optimum Utilization of Plant Layout: A Case Study. International Research Journal of Engineering and Technology (IRJET). Volume: 04 Issue. 06 June 2017. e-ISSN:2395-0056. P-ISSN: 2395-0072.

Wibowo. 2010. Manajemen Kinerja. Penerbit: Rajawali Press. Jakarta.

Wiyaratn, W. and A. Watanapa. 2010. Improvement Plant Layout Using Systematic Layout Planning (SLP) for Increased Productivity. International Journal of Industrial and Manufacturing Engineering Vol:4. No:12. 2010. ISNI:0000000091950263.

Yamit, Zulian. 2005. Manajemen Operasi dan Produksi Edisi Kedua. Penerbit: Ekonisia. Yogyakarta. 